\title{
REGIONAL NEEDS ASSESSMENT: AN APPROACH TO DEMOGRAPHIC AND MIGRATION RESEARCH
}

\section{Pētījumi demogrāfijā un migrācijā: vajadzību novērtēšana reǵionos}

\author{
Elina Apsite-Berina ${ }^{1}$, Baiba Bela ${ }^{1}$, Maris Berzins ${ }^{1}$, Dina Bite ${ }^{2}$, Zaiga \\ Krisjane $^{1}$, Juris Krumins ${ }^{1}$, Zenija Kruzmetra ${ }^{2}$, Velta Lubkina ${ }^{3}$ \\ ${ }^{1}$ University of Latvia \\ ${ }^{2}$ Latvia University of Life Sciences and Technology \\ ${ }^{3}$ Rezekne Academy of Technologies \\ e-mail: elina.apsite-berina@lu.lv
}

\begin{abstract}
This study exposes approaches to "collective creativity"by adopting a regional needs assessment through the World Café method. A multidisciplinary team of researchers and stakeholders worked together to identify needs within the region by using the World Café method and enhancing participation in policy-making. The paper aims to describe regional needs assessment as a useful approach for studying demographic and migration challenges in the regions of Latvia. The formal outcomes of the project are policy recommendations which have been used for the elaboration of planning documents at the national, regional and local level. Moreover, this approach also fostered positive collaborative practices among scientists and policymakers, including scientists who come from various disciplines and found a common platform for the solution of problems.
\end{abstract}

Keywords: demographic and migration challenges, regions, Latvia, needs assessment DOI: $10.22364 /$ fg. 18.1

\section{Introduction}

In this paper, we explore an innovative approach - regional needs assessment through networking with regional stakeholders using the "World Café method" (Lohr et al. 2020). A needs assessment is a systematic process to identify and address needs or "imperfections" in the current situation and identify how more desirable circumstances could be achieved. Needs assessments help to improve the quality of policies, thereby improving performance and making it more likely to achieve desired outcomes (Watkins et al. 2012; Altschuld and Watkins 2014; Morris 2015). The World Café method complements other qualitative data-gathering methods in several ways (Lohr et al. 2020), as well as enhancing "collective creativity" (Senge 2005). Firstly, according to Lohr and colleagues, it helps with organising discussions better, clarifying the themes and increasing the level of participation. It has also been used as a novel method in several fields of research: for example, in research into learning (Tan and Brown 2005; Bush and Paranjpey, 2015), into strategic planning among economic actors (Chang and Chen 2015), and into the well-being of particular societal groups (Clements et al. 2020).

There is evidence of the usefulness of the World Café method in the case of Latvia, it has also been used, for example: in discussing a maritime spatial plan for the 
west coast of Latvia (Ruskule and Veidemane 2011), and at a regional youth forum in Kurzeme (Kurzemes..., 2013).

As a method, it fosters mutual dialogue and learning. Furthermore, in cases when policymaking representatives are involved, it increases the level of "good practice" exchange. Needs assessments also involve networking practices and enables participants to explore qualitative statements and to carry out assessment of regional strengths, weaknesses, and opportunities. In this case, particular attention is paid to issues related to demographic and migration challenges, and regional and local potential for culture-based development. Regional events enhance public involvement and cross-disciplinary approaches to migration and responses to demographic challenges. A needs assessment is a systematic process to identify and address needs or "imperfections" in the current circumstances and identify how more desirable circumstances could be reached. Needs assessments help to improve the quality of policies, making it more likely to be achieve desired outcomes (Watkins et al. 2012; Altschuld and Watkins 2014; Morris 2015).

Two issues were considered while planning the research. Firstly, available statistical data insufficiently allows representation of the impact of migration on demographic issues. Thus, it is imperative to know and understand how the situation is interpreted by local people who live in the regions, as well as how they feel, and how emigration and depopulation affect their daily lives and change the areas in which they live. Regional workshops of this kind were seen as a useful tool for researchers in looking at the situation in the regions from a grassroots perspective. Secondly, it is essential for a group of researchers from different sectors and universities who start working together on a joint project to ensure integrated action and a common starting point. These regional workshops were also crucial for researchers to get to know each other, to understand the themes of each team and to further explore their subjects on the basis of shared knowledge.

The regional workshops aimed to gather views on the demographic development and migration processes of those living and working in the region. The diverse range of participants allowed for fundamental problems to be identified, as well as examples of good practice and possible solutions for the sustainable development of the region.

\section{“DemoMig" project}

The complicated relationship between demographic change and migration has attracted a large body of previous research around the world (Hugo 2011; Findlay and Wahba 2013). The problems caused by low fertility rates, the ageing of the population and increasing out-migration have negative consequences for demographic change and the development of a sustainable and inclusive society in Latvia. Depopulation and outflows from particular age cohorts contribute to demographic imbalances and the loss of human capital. Moreover, the negative consequences of demographic change and migration have territorial 
implications, affecting more remote settlements and contributing to regional disequilibrium. These significant demographic and migration challenges are a critical socio-economic issue in terms of presenting barriers to sustainable development and the growth of an inclusive society; thus, more profound studies are needed to assess and find a response to the depopulation of Latvia.

The study is based on the project "Towards Sustainable Development and an Inclusive Society in Latvia: A Response to Demographic and Migration Challenges (DemoMig)", part of the national research programme "Latvian Heritage and Future Challenges for Sustainable Development". This project has been running for 36 months, since December 2018, and aims to assess and respond to migration and demographic challenges in order to foster sustainable development and an inclusive society in Latvia. The application of an interdisciplinary approach enables the research to examine the following themes: an exploration of migration trends and continuing natural population decline and the regional dimensions of these issues in Latvia, as well as an exploration of the importance of culture in the revitalisation of regions. The project results provide a comprehensive overview of demography, migration, social sustainability and inclusive society and regional specifics. The primary outcomes of the demographic and migration shifts and of the assessed regional diversity are described and mapped. The societal impact of migration and demographic challenges within the context of highly valuable human capital resources are described, and talented and highly skilled individuals are identified. The role of higher education concerning human capital loss and the promotion of policies aimed at avoiding a brain drain of highly skilled students and educators is evaluated. The role and importance of culture-based resources assessed in the context of the potential for revitalisation of the region. Tools for evidence-based policy recommendations are provided for the growth of a sustainable and inclusive society in Latvia.

Statistical data show the extent of emigration and immigration, inequalities and poverty, employment and average wages. In order to successfully launch the study, an in-depth understanding of the situation in the regions is required. Nevertheless, these quantitative data do not help us to understand how problems are seen and interpreted by the people who live in these regions. For this reason and in order to carry out an assessment of the region's needs, a multidisciplinary team of researchers was chosen to identify and involve the local population in a method of assessing the needs of the region, using the World Café method (Brown 2010; Pagliarini 2006) which is used extensively for societal involvement (Lohr et al. 2020).

\section{Data and methods}

In order to perform regional needs assessments within the context of project research plan, six regional workshops were organised with stakeholders to enhance public involvement and strengthen the cross-disciplinary elaboration. A regional needs assessment was carried out through a discussion with stakeholders on the topics 
of strength, weaknesses and opportunities in the fields of demographic and migration challenges, and issues of education and culture-based development.

For the discussions, the "World Café" method (Brown 2010) was used, which ensured a participatory approach to generating new knowledge and sufficient group work to discuss these topics.

The regional workshop structure included several vital principles. Besides creating a hospitable space for the discussion of relevant questions, the moderator encouraged everyone to take part by creatively characterising the traditional views of locals living in a particular region.
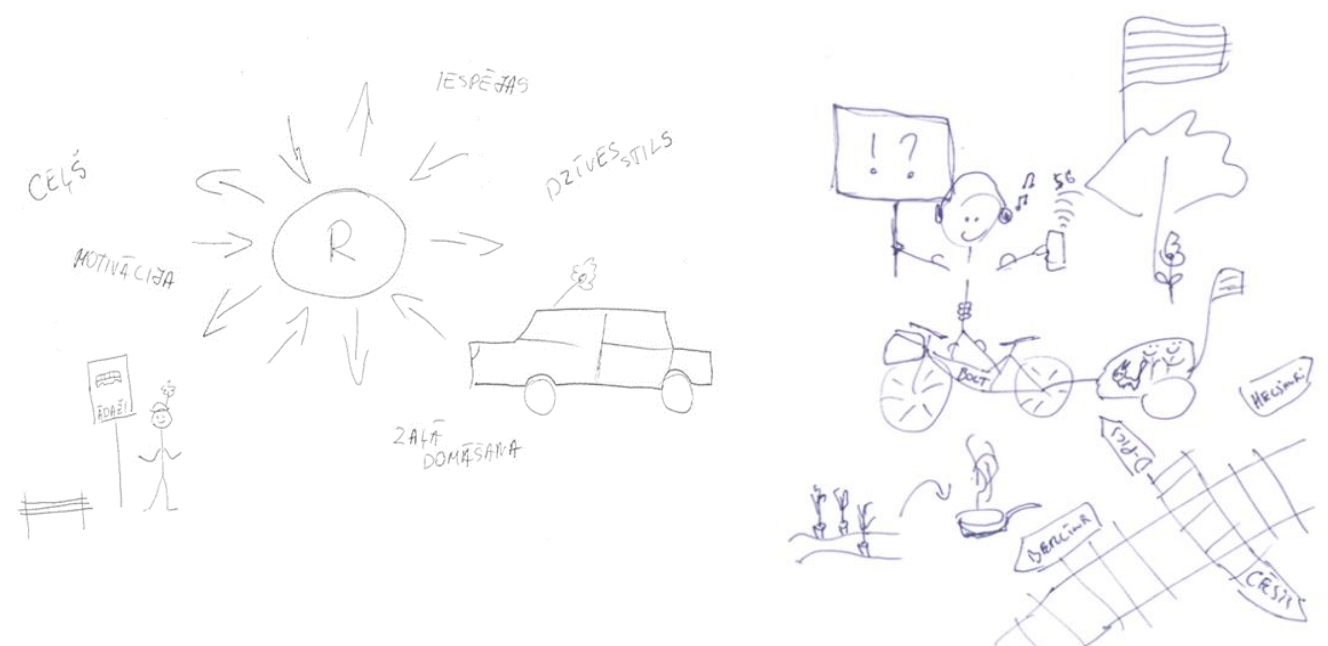

Figure 1. Collective creativity about Riga and Pieriga region (field work material)

Participants in the regional workshops discussed five main topics, and each of these included five sub-topics. Thus, the total number of discussed questions was 25 . The main topics concentrated on were the following:

- The role of education in retaining and attracting a skilled workforce

- Migration of qualified specialists

- Culture as a driving force in regional development

- Demographic processes and migration

- Demographic policy

The World Cafe method appeared a great way for participants to discuss important issues and create a joint knowledge base. It is suitable for discussing current issues and new ideas, and for finding relevant solutions, as well as establishing a dialogue between the various participants in the discussion group. The name of the method is an appropriate metaphor because the workshop is like a café where different people meet. There is an exchange of thoughts and opinions, of new ideas, and of shared knowledge. Furthermore, the collected data material from the discussions is transcribed, generalised and edited, transposing it to the texts describing a particular topic. 
The participants in the regional workshops represented members of planning regions, municipalities, non-governmental organisations, entrepreneurs and mixed population groups.

Table 1 . The number of participants by regional needs assessment workshop

\begin{tabular}{|l|c|c|c|c|c|c|}
\hline Regional event & Kurzeme & Zemgale & Vidzeme & Latgale & Pieriga & Riga \\
\hline Number of participants & 30 & 40 & 42 & 48 & 37 & 51 \\
\hline
\end{tabular}

In total, six regional events were organised, in addition to a further closing event. The schedule of regional events from late May 2019 to the closing event in midJanuary 2020 is shown in Figure 2.

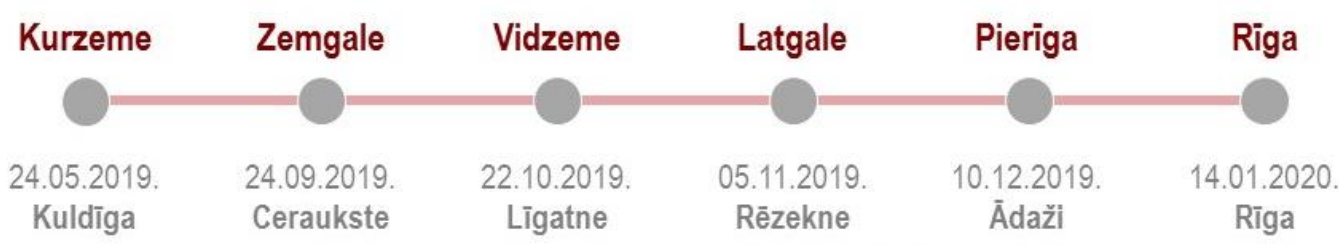

Figure 2. Calendar of regional events, May 2019-February 2020 (authors' figure)

Furthermore, around 120 participants gathered for the final event, which took place in mid-February.

The regional events were organised in collaboration with the planning regions of Latvia. Practicalities such as choice of the venue, the date, production of informative materials, dissemination of materials, invitations were settled in a mutually collaborative manner with the participation of scientists, representatives from the planning regions and those involved in the particular event.

\section{Results: Challenges and Solutions in the regions of Latvia}

The main output of the information gathered at the regional workshops was further elaborated on by the thematic teams of scientists. Each team had to prepare a report on the topic. In the majority of the cases, reports focused on providing a description of the current situation, exposing the main challenges the particular region or individual was facing, and, finally, presenting practical solutions and recommendations to policymakers. Furthermore, posters were created for each regional workshop to display the main features and the most common recommendations. 
Latvijas mantojums un nākotnes izaicinājumi valsts ilgtspējai

\|lgtspèjīgas un saliedētas Latvijas sabiedrības attīstība:

risinājumi demogrāfijas un migrācijas izaicinājumiem (DemoMig)

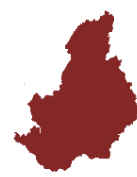

LATGALE

Reǵionālo ideju darbnīcu apkopojums

Latgales iedzīvotājs

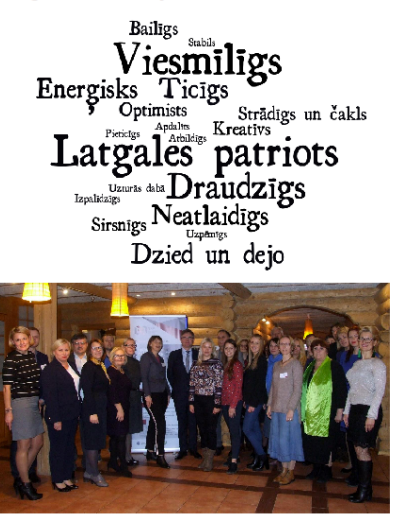

口는. VPP projekts: DemoMig

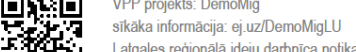

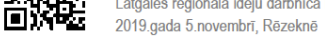

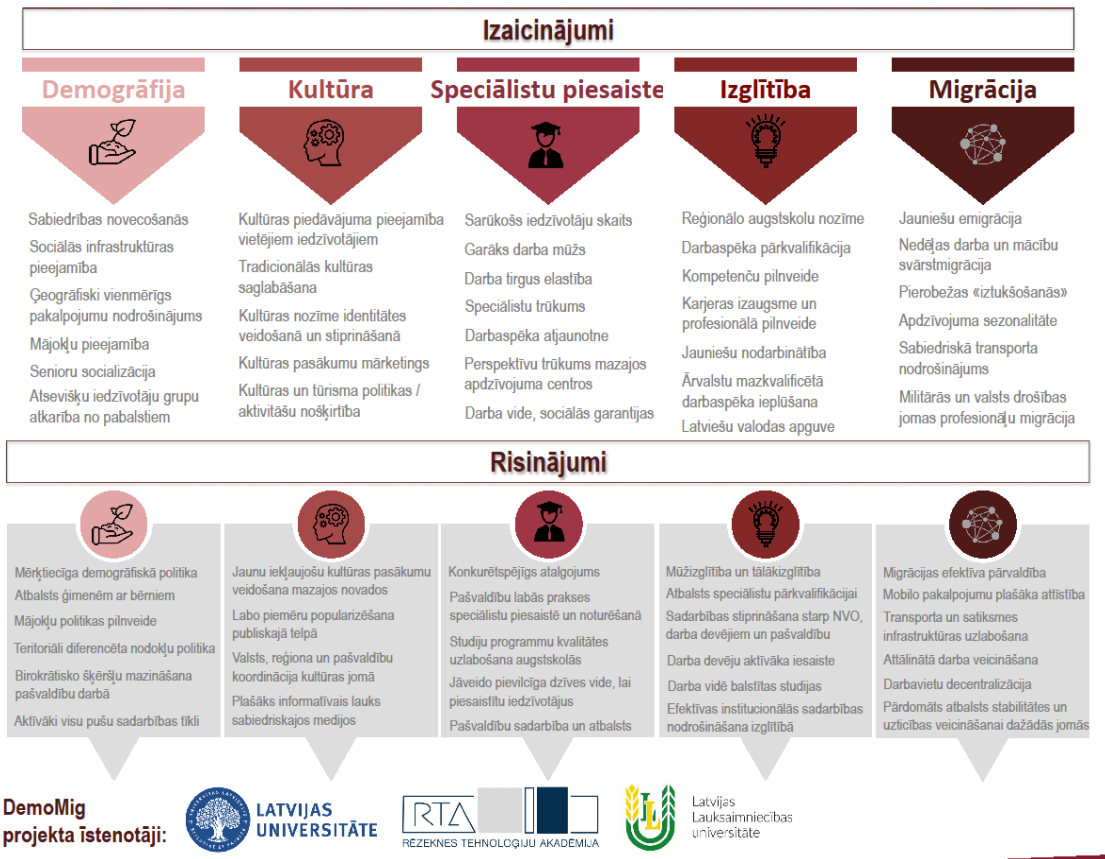

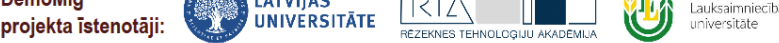

NR.VPP-IZM-2018/1-0015

Figure 3. Challenges and solutions in Latgale region: a summary of the regional workshop (authors' figure)

The final stage of the qualitative material gathered with the World Café method was an elaboration of the policy recommendations, which were systemised according to the region and the topic: education, qualified specialists, culture as a driving force, migration and demographic policy. In addition to this, thematic division topics were covered by the expert scientific teams. For example, issues related to demographic policy were covered by demographers, issues related to the qualified migrant workforce and the importance of culture were examined by sociologists. Human geographers addressed complex issues related to demographic processes and migration patterns. Pedagogical experts examined the essential issues of human capital attraction and retention in the regions. 


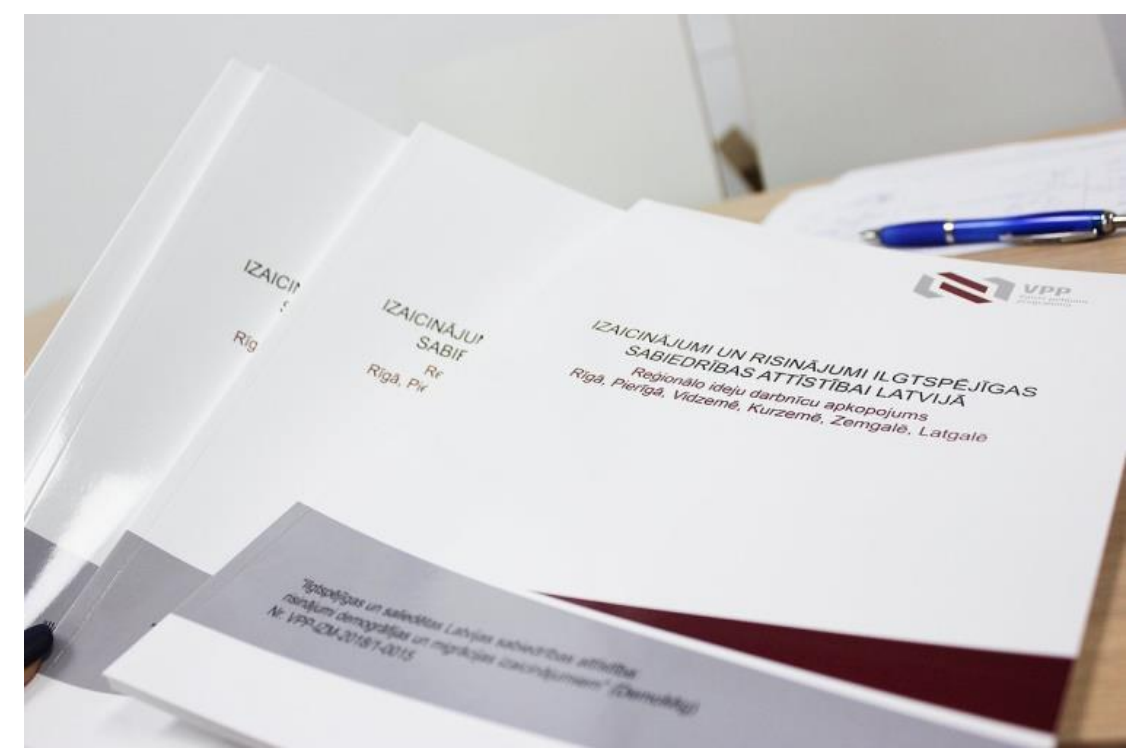

Figure 4. Policy recommendations leaflet. Challenges and solutions for sustainable societal growth in Latvia. Summary of regional workshops: Riga, Pieriga, Vidzeme, Kurzeme, Zemgale, Latgale (authors' photography)

\section{Conclusions}

This paper aimed to explore regional needs assessment though the application of the World Café method, which strengthens collaboration and personal networks, and encourages mutual learning (Steier et al. 2015; Tan \& Brown 2005). According to Stetier et al. (2005) "collective creativity" fosters the widening of local knowledge and broadening of mutual dialogue (Greenwoord \& Levin 2007).

The practical application of the method included several originally designed principles such as 1) setting the context; 2) creating a friendly environment; 3) exploring relevant topics; 4) enhancing collaborative creation; 5) blending and connecting different views; 6) co-creating local knowledge; 7) sharing joint discoveries (Brown 2010).

Latvia as a country is experiencing depopulation, and a substantial share of the population is ageing, thus tailor-made policies are crucial. For this reason it is vital to explore and assess local knowledge on demographic and migration challenges within the region. Regional workshops enhance networking and exchange of good practice among scientists, policymakers and regional planning bodies and various groups in society.

The formal outcomes of the project are policy recommendations which have been used for the elaboration of planning documents at the national, regional and local level. Moreover, it has also fostered positive collaborative practices among scientists and policymakers, including scientists who come from various disciplines and found a common platform for the solution of problems.

The main thematic results covered in the regional needs assessment events are synthesised in the policy recommendation leaflet "Challenges and Solutions to Sustainable Societal Growth in Latvia. Summary of Regional Workshops: Riga, 
Pieriga, Vidzeme, Kurzeme, Zemgale, Latgale" which has been published and is also available online (ej.uz/DemoMigLU).

\section{Acknowledgement}

This work was supported by the National Research Program Project grant number VPP-IZM-2018/1-0015 and ERDF grant 1.1.1.2/VIAA/1/16/184.

\section{Kopsavilkums}

Šajā pētījumā tiek izmantota reǵionālo vajadzību novērtējuma pieeja. To veido starpdisciplināra pētnieku grupa, kas strādāja pie reǵionu vajadzību identificēšanas, izmantojot pasaules kafejn̄icas metodi. Tādējādi darba mērḳis ir aprakstīt reǵionālo vajadzību novērtējumu kā noderīgu pieeju demogrāfisko un migrācijas problēmu izpētei Latvijas reǵionos. Projekta rezultāti ir politikas ieteikumi, kurus plaši izmanto plānošanas dokumentu izstrādei nacionālā, reǵionālā un vietējā līmenī. Turklāt tas ir veicinājis pozit̄ivu sadarbības praksi starp politikas veidotājiem un sabiedrību, kā arī starp dažādu nozaru zinātniekiem, kuri tādā veidā rod risinājumus daudzveidīgajiem izaicinājumiem reǵionos.

\section{References}

Brown, J. (2010). The world café: Shaping our futures through conversations that matter. ReadHowYouWant.com.

Bushe, G.R. and Paranjpey, N. (2015). Comparing the generativity of problem solving and appreciative inquiry: a field experiment. Journal of Applied Behavioral Science, 51 (3), 309-335.

Chang, W.L. and Chen, S.T. (2015). The impact of World Café on entrepreneurial strategic planning capability. Journal of Business Research, 68 (6), 1283-1290.

Clements, A.J., Sharples, A., and Kinman, G. (2020). Identifying well-being challenges and solutions in the police service: A World Café approach. The Police Journal.

Findlay, A.M. and Wahba, J. (2013). Migration and demographic change. Population, Space and Place, 19 (6), 651-656.

Greenwood, D. J. and Levin, M. (2006). Introduction to action research: Social research for social change. SAGE Publications.

Hugo, G. (2011). Future demographic change and its interactions with migration and climate change. Global Environmental Change, 21, 21-33.

Kurzemes jauniešu reǵionālais forums "Ievirzi Kurzemi" (2013). Pasaules kafejnīcas darba grupu rezultātu apkopojums. https://jaunatne.gov.lv/sites/default/files/web/Jaunumi/Sveice/Pasakumi/pasaules_kafe_apkopojums.pdf

Löhr, K., Weinhardt, M. and Sieber, S. (2020). The "World Café" as a Participatory Method for Collecting Qualitative Data. International Journal of Qualitative Methods, 19.

Pagliarini, R. (2006). The World Café - Shaping Our Futures through Conversations that Matter. Journal of Organizational Change Management, 19 (2), 266-268.

Ruskule, A., and Veidemene, K. (2011). Developing a Pilot Maritime Spatial Plan of the Western Coast of Latvia. Environmental Forum Latvia, 10.

Senge, P.M. (2005). Discovering the Magic of Collective Creativity. Afterword to J. Brown's World Café. San Francisco: Bennett Kohler, Inc.

Steier, F., Brown, J. and Mesquita da Silva, F. (2015). The World Café in action research settings. The SAGE Handbook of Action Research, 3, 211-219.

Tan, S. and Brown, J. (2005). The World Café in Singapore: creating a learning culture through dialogue. Journal of Applied Behavioral Science, 41 (1), 83-90. 